\title{
Reimaging Post COVID-19 Global Value Chain: Case Study of Automotive and Electronic Companies in China
}

\author{
Rizky Anggia Putri \& Maula Hudaya \\ Universitas Gadjah Mada
}

\begin{abstract}
The outbreak of the COVID-19 pandemic at the end of 2019 caused various problems for the international community, especially China as the outbreak's epicenter. With the enactment of a lockdown policy in China, various activities involving human interactions, especially economic activities, are limited and can potentially disrupt the global value chain as China is the world's factory. In this paper, we examine the impact of the pandemic on the Global Value Chain (GVC) in China. The authors argue that the pandemic has forced the companies that integrated with GVC to rethink their strategy on keeping the production process running well. This paper analyzes the impact of pandemics on the GVC in China by comparing the historical trajectories, actor's strategies, and regulations before and after the pandemic. We compare these indicators before and after the pandemic to determine how they affect the GVC system and how companies adapt to the disruption by rethinking and readjusting their strategies. Thus, the analysis can conclude whether the fragmented GVC system is still relevant or needs an entirely new system with more resistance to phenomena like the COVID-19 pandemic.
\end{abstract}

Keywords: The COVID-19 pandemic, Lockdown, Fragmented Global Value Chain, Companies Operated in China

Merebaknya pandemi COVID-19 di penghujung tahun 2019 menimbulkan berbagai permasalahan bagi dunia internasional khususnya Tiongkok sebagai episentrum penyebaran virus. Dengan diberlakukannya kebijakan lockdown di Tiongkok, berbagai aktivitas yang melibatkan interaksi manusia, khususnya aktivitas ekonomi, menjadi terbatas dan berpotensi mengganggu rantai nilai global karena Tiongkok adalah pabrik dunia. Dalam tulisan ini kami membahas dampak pandemi pada Global Value Chain (GVC) di Tiongkok. Penulis berpendapat bahwa pandemi telah memaksa perusahaan yang terintegrasi dengan GVC untuk memikirkan kembali strategi mereka dalam menjaga agar proses produksi tetap berjalan dengan baik. Tulisan ini menganalisis dampak pandemi terhadap GVC di Tiongkok dengan membandingkan lintasan historis, strategi aktor dan regulasi sebelum dan sesudah pandemi. Dengan membandingkan indikator-indikator tersebut di masa sebelum dan setelah pandemi, akan membantu untuk mengetahui bagaimana pandemi memengaruhi sistem GVC dan bagaimana perusahaan beradaptasi terhadap gangguan dengan memikirkan dan menyesuaikan kembali strategi mereka. Dengan demikian, analisis tersebut dapat digunakan untuk menyimpulkan apakah sistem GVC yang terfragmentasi masih relevan atau ternyata diperlukan sistem yang benar-benar baru yang lebih tahan terhadap fenomena pandemi COVID-19 tersebut.

Kata-kata Kunci: Pandemi COVID-19, Lockdown, Global Value Chain Terfragmentasi, Perusahaan yang beroperasi di Tiongkok 
Since the first outbreak in December 2019 in Wuhan, China, there have been no signs that the COVID-19 pandemic will end any time soon. On the contrary, the trend of COVID-19 cases has continued to increase consistently since the beginning of 2020 . Even the latest data from December 2020 showed that COVID-19 cases worldwide had reached more than 70 million, with the death rate almost exceeding 1,6 million people (WHO 2020). China itself confirmed 96,000 positive cases and 4,782 death cases in 2020 (Statista 2021). The rapid spread of the COVID-19 outbreak has forced various countries to take extreme preventive measures, from social restrictions to the total lockdown.

As a result, people's mobility domestically and internationally has become strictly limited because of limitations on immigration policies. Moreover, many countries limit the mobility of people and severely restrict the movement of goods through tightening customs policies (Bertasiute et al. 2020; Indonesian Ministry of Finance 2020). As a result, Gopinath (2020) stated that the world has been put in a Great Lockdown, where the scale and speed of the downfall of various activities, especially the economy, are unimaginable and unprecedented. Gopinath (2020) further argued that the abovementioned condition could potentially have enormous economic consequences, even lead the world into an immense crisis after the Great Depression and much worse than the 2008 Global Financial Crisis.

The Great Lockdown affects the financial sector and potentially causes severe disruptions to the Global Value Chain (GVC). Several academics have raised the issue of the Covid-19 pandemic and the GVC in their research. Roger Strange (2020), in "The 2020 COVID-19 pandemic and global value chains" examined the impact of COVID-19 pandemic on firm's strategies, focusing the analysis in the configuration of its GVC by comparing the merits of alternative location strategies (international diversification vs. reshoring) as are the merits of different governance arrangements (internalization vs. externalization) for GVC activities. Hayakawa and Mukunoki (2021), in "Impacts of COVID-19 on Global Value Chains" examine bilateral trade in finished machinery products from January to June in 2019-2020 by using the numbers of COVID-19 cases and deaths as measures of the 
impact of the pandemic. Patel-Campilo (2010), in "Transforming Global Commodity Chains: Actor Strategies, Regulation, and Competitive Relations in the Dutch Cut Flower Sector" examine how actor strategies, regulation, and historical trajectory of the Dutch cut flower GCC shape and change the governance chain. Our discussion in this paper seeks to analyze how the Great Lockdown affects GVC in China using the same indicators used by Patel-Campilo, then assess whether the current GVC system is quite relevant when faced with such enormous challenges at a global level such as the current COVID-19 pandemic. To make this research more specific, we focused on GVC in the electronics and automotive sectors since these sectors play a significant role by dominating the offshore value chain in China.

\section{Historical Trajectories, Actor's Strategy and Regulation}

Patel-Campilo (2010) highlighted the importance of the legacy of historical trajectory on their research as a key factor to measure a GVC phenomenon combined with the actor's strategy and regulation. The actor's strategy consists of informal partnerships or alliances involving organizational functions and regimes that issue regulations. Strategic partnerships include a range of competitive, process-based, function/technology, and/or spatial features. The process-based partnership strategy includes an arrangement whereby suppliers can work together in one or various segments of the production process to respond to competitive pressures by increasing productive activities, lowering costs, spreading risk throughout the company, and arranging for productive use of resources to be utilized in an effective manner or more efficient among others. Function/technology-based strategic partnerships enable suppliers collectively to increase their relative position vis-à-vis their competitors by pooling resources and distributing specialized functions and competencies across a wider supplier network. The partnership arrangement also allows suppliers to reposition themselves on the world market by expanding their geographical reach domestically and internationally. PatelCampilo (2010) also stated that regulation and strategic alliances are an intrinsic part of regulating the global commodity chain. 
In this paper, the historical trajectories section presents a historical perspective about GVC in China that shows historical sequences in which contingent events set into motion institutional patterns or event chains with deterministic properties. This section will track the history of GVC in China; its early development; the transformation that occurred before the pandemic; and the current conditions after the COVID-19 pandemic. The Actor's Strategies and Regulation section will examine the strategies used by related actors in response to China's government's regulation to survive in the global competition of GVC in China by looking through two conditions, namely before and after the pandemic. Finally, this paper will explain how the government's regulations affect the development and transformation of the GVC in China before and after the COVID-19 pandemic.

\section{Global Value Chain in China Before and After COVID-19: Historical Trajectory}

\section{GVC Fragmentation in China before COVID-19}

The current GVC system is a product of the phenomenon of economic globalization. As Gereffi et al. (2005) and Steger (2003) stated, the rapid development of information, communication, and transportation technology coupled with changes in economic policies from protectionist to more open policy has enabled the economic interconnected and interdependence between various countries around the world made it possible to distribute goods globally and rapidly. Meanwhile, policies to liberate the economy initiated by countries with great economic powers led to what Steger (2003) called the neoliberal revolution. This revolution minimized state control of the economy while at the same time making state policies that were previously protectionist to be open so that economic integration across borders, including GVC and global markets, could develop rapidly. The significant development of information, communication, and transportation technology supported by the neoliberal revolution made economic globalization possible (Gereffi et al. 2005; Steger 2003). It then led to a vertically integrated production system, which is 
implemented by not only focus on producing its main product but also controls, even with direct ownership of the production of supporting goods which function as raw materials for the production of the company's main products (Gereffi et al. 2005). Therefore, the vertically integrated production system itself can be said to be a less efficient system. As explained by Gereffi et al. (2005), a vertically integrated company controls all elements of its production. Departing from these conditions, the inefficiency of this system is divided into two points, namely quality and cost. When a company controls all of the production elements by itself, the quality of the product becomes the biggest stake. In addition, owning all elements of production also leads to inefficiency in production costs. This argument is also supported by Debanes (2018), who observed South Korean MNCs' development in the 1990-2015 period. In his work, Debanes (2018) states that one of the causes of the delay in the development of South Korean MNCs amidst the rapid development of Chinese companies lies in the vertically integrated system, which South Korean MNCs still tend to embrace.

Nowadays, companies around the world mostly shift to a new pattern of GVC called fragmented GVC. It benefits companies by making them no longer need to create complete products or value chains. By implementing fragmented GVC, these firms "insert themselves" into a particular stage of production along the value chain that suits their existing level of capability so that they can create targeted industries (Seric and Yee 2020). The practice of fragmented GVC itself is apparent in China. The data in 2005 showed that more than 500,000 foreign multinational companies were operating in the country (Blanchard 2007). Investopedia (2021) stated that until early 2020 China was still the favorite investment destination for large companies in various parts of the world. The American electronics and automotive companies such as Apple, Dell, Microsoft, Intel, HP, and General Motors run their operations in China. Apart from US companies, multinational companies from various other parts of the world also operate in China. For example, automotive and electronic companies from Japan, Korea, and Europe, such as Toyota, Honda, Mitsubishi, Subaru, Samsung, LG, Kia, Hyundai, and BMW (Investopedia 2021; Blanchard 2007; Yilei et al. 2019). 
Chen (in Gereffi and Korzeniewicz 1994) stated that since China opened its economy during the economic reforms, the country has been known to have a large and cheap workforce. It made several neighboring countries such as Hong Kong and Taiwan become the first countries to concentrate their production activities in China, especially in industrial sectors that require much labor, such as electronics, garment, and footwear industries. The loosening of government policies related to FDI and the availability of cheap labor in large numbers, or what Chen (in Gereffi and Korzeniewicz 1994) called China's comparative advantage, made various multinational companies worldwide interested in investing in China. Most of the investment was realized by making China a production center as well as a supplier of raw materials and spare parts for the main products of these companies. Two industrial sectors that currently dominate the offshore value chain in China are the electronic equipment industry and the auto parts industry. Shedletsky (2019) stated that many of the world's leading electronics manufacturers rely on China as their production center because industrial facilities in China allow cheap, fast, and efficient production processes.

Coffin (2019) stated that the Chinese automotive industry is very reliable in the automotive spare parts sector because China has developed its automotive industry capabilities since 2007. Until 2019, China is one of the major automotive parts exporters supplying spare parts to various automotive companies worldwide. Coffin (2019) states that the United States automotive industry relies on China as one of the leading suppliers of automotive parts for the country, as well as Europe, Japan and Korea also rely on China in their production processes.

Based on this explanation, it can be seen that China is one of the important links in fragmented GVC for multinational companies in various parts of the world, especially electronics and automotive companies. However, there have been changes, especially regarding the government policies during the COVID-19 pandemic. This condition raises the question of whether the pandemic is disrupting the stability of GVC fragmentation in China. Then, what is the response of various companies, especially electronics and automotive, whose GVC is connected to China. 


\section{GVC Fragmentation in China after COVID-19}

In January 2020, the Chinese government decided to completely close at least 13 cities in Hubei province, where the SARS-CoV-2 virus was alleged to have originated (Leung 2020). The Chinese government takes the tightening policies, which also touched on production support sectors such as the closure of warehouses owned by various companies and the strict restriction of export and import activities. This condition creates confusion and losses for industrial actors, even the president of the European Chamber of Commerce in China, Joerg Wuttke, called this condition a "logistical nightmare" (Mistreanu 2020). The policy of closing production activities and the "logistical nightmare" impacts the highly complex and globally integrated supply chain. Various spare parts from this industry, generally come from different countries, are assembled into a finished product somewhere (Zhang 2020). So that the electronic and automotive goods industries, which are part of this type of industry, experience a significant impact due to the tightening policy.

As one of the leading electronics industries, Apple claims that its global supply chain is experiencing disruption due to lockdown policies in China and a "logistical nightmare". Even the Apple factory in iPhone City, Zhengzhou, also experienced a prolonged shut down after the 2020 Chinese New Year (Gurman and Wu 2020). Apart from the shutdown of production, disruptions to Apple's supply chain also came from the spare parts supply sector caused by the "logistical nightmare". Barboza (2021) stated that to produce just one iPhone unit, Apple brings in parts from 200 different suppliers spread across various countries in the world. During the tight export and import regulations, the spare parts supply chain will not run smoothly compared to its normal situation. Apple CEO, Tim Cook, confirmed that Apple experienced supply chain disruptions due to the lockdown policy. He also stated that Apple was contemplating mitigation measures to overcome the cut-off from one of its suppliers in Wuhan; regarding the suppliers from outside of Wuhan and outside China, Cook stated that Apple was in a state of uncertainty (Collins 2020). 
Sony, another electronic company, took a shutdown policy on its four manufacturing plants in China (two in Shanghai; one in Wuxi, Jiangsu; and one in Huizhou, Guangdong). This decision started on 24 January until 9 February 2020. Sony admitted that the COVID-19 pandemic and its lockdown policy did impact their supply chain, especially in China, as Chinese manufacturers mostly made their camera products. Sony highlighted the business impact as a continuation of lockdown policy towards its Imaging \& Sensing Solution segment, in which its customers primarily derived from smartphone industries that rely on supply chains in China. Therefore, the pandemic risks this segment's upcoming sales, which a slowdown in the smartphone market caused. Another impact of the lockdown policy is making it difficult for them to send engineers to China as manufacturing hubs to help with the launching process of new products or give instructions on manufacturing (Sony 2020).

The automotive industry also experiences the same condition. Wuhan is also known as "Detroit of China", the largest automotive production center in China, contributing to $10 \%$ of all automotive production in the country. Wuhan is also the home of hundreds of automotive spare parts suppliers who export to various parts of the world; several large automotive companies such as Honda and General Motors also have production centers in Wuhan. This condition causes interference with automotive GVC in two ways. First, the lockdown policy in Wuhan made automotive production activities in the region completely stopped for a long time, which contributed to the significant decrease in automotive production in the region. Second, GVC disruption is also experienced by automotive companies operating outside of China because various leading automotive companies worldwide rely a lot on the supply of spare parts from China, especially Wuhan (Zhang 2020).

In March 2020, Honda, whose production centers were directly affected by the Wuhan lockdown, predicted that their profits in 2020 would decrease by at least $3 \%$ compared to the previous year (Hara 2020). The impact was even worse for Hyundai, where the brand was the first major automotive brand to decide to suspend production in South Korea due to a shortage of spare parts imported from China. The same condition was experienced by the 
leading Italian automotive company, Fiat, which also postponed its production in Italy due to a shortage of spare parts from China. On the other hand, Suzuki is considering looking for other parts suppliers outside of China to deal with the impact of disruption to the supply chain due to the COVID-19 pandemic (BBC 2020). The same action was implemented by one of the spare parts suppliers for a Japanese automotive company, Mazda, which operates in Jiangsu, China. The company shifted the production of its spare parts to Guanajuato, Mexico, to avoid the impact of COVID-19 in China (Tajitsu and Shiraki 2020).

\section{Global Value Chain in China Before and After COVID-19: Actor's Strategies and Regulation}

As an important link in the GVC of the companies mentioned above, China has three roles in the value chain simultaneously, namely as Original Equipment Manufacturers (OEMs), tier 1 suppliers, and tier 2 suppliers (Amatech 2021). China's role as OEMs can be seen in electronics companies such as Apple, Sony and automotive companies such as Honda and General Motors. For example, Apple is known to have a production center or assembly point operated by Foxconn in Zhengzhou city, also known as iPhone City, because it handles half of all iPhone production in the world. In this production center, parts from more than 200 suppliers around the world are put together into a complete iPhone and then sold worldwide (Barboza 2021). Likewise, Sony's business segments rely on the supply chain in China before it is made into finished products by its customers. Similarly, Honda and General Motors, the two automotive companies, also have a production center or assembly point in Wuhan, known as the "Detroit of China", because it is the home of various OEMs and large automotive industry suppliers (Zhang 2020).

Then the role of China as a tier 1 supplier is apparent in the Mazda case. The company relies heavily on the supply of major spare parts from China. It appears that Mazda has strong cooperation with the tier 1 supplier company because Mazda is ultimately able to influence the company to move its spare parts production center due to the impact of the COVID-19 pandemic (will be explained further in the next section) (Tajitsu and Shiraki 2020). Lastly, as 
a tier 2 supplier, China's role is noticeable through automotive manufacturers in the United States. Coffin (2019) stated that 86\% of all domestic-produced car electrical components in the United States, including lamps, generators, and wiring, are imported from China. According to him, these components are tier 2 supplier products imported by tier 1 suppliers and then distributed to OEMs.

Thus, it is apparent that many companies in the world entrust China as one of the important links in their GVC fragmentation. Moreover, as the "world's factory", China is the home of $28 \%$ of the world's industries; the number is almost as large as the United States, Japan, and Germany combined. More than that, China also has a complete supply chain, even it claimed to contribute to half of all supply chains in the world, with production levels reaching nearly 120 million products per day (China Daily 2020).

\section{Actor's Strategies and Regulation in China Before COVID-19}

China's position as the most important link in the GVC of various companies globally cannot be separated from the regulations that make it easier for these companies to operate and the attractive comparative advantage. Zhang (2001) and Chen (in Greffi and Korzeniewicz 1994) agree that the first regulation that allowed China to achieve this position began in 1978 when the government decided to open its previously closed economy by implementing the "Law of Sino-Foreign Joint Venture" policy to facilitate the entry of FDI. The policy on FDI, which continues to loosen over time, has increasingly attracted foreign companies to operate in China (Preen 2019). These comparative advantages include the availability of cheap labor in large quantities and the absence of trade unions due to the authoritarian socialist government system (Chen in Gereffi and Korzeniewicz 1994; Loyalka 2012).

This condition makes various foreign companies implement strategies according to the existing government regulations, namely by establishing cooperation or collaboration with local companies. In this case, the leading electronics company, Apple, collaborates with Foxconn to run its production center in iPhone 
City, Zhengzhou (Barboza 2021). Apple also established a joint venture with a local company in China, Guizhou - Cloud Big Data Industry Co Ltd (CNBC 2018). Besides Apple, other electronic companies also collaborate with local electronic companies in China to run their production; it can be seen in the following table:

Table 1.

Foreign Electronic manufacturer on joint ventures with China's company

\begin{tabular}{|l|l|}
\hline \multicolumn{1}{|c|}{$\begin{array}{c}\text { Foreign } \\
\text { Electronic } \\
\text { Manufacturer }\end{array}$} & \multicolumn{1}{c|}{ Joint Ventures (with) } \\
\hline Fujitsu & INESA Intelligent Technology Co., Ltd. \\
\hline Toshiba & $\begin{array}{l}\text { Nantong Fujitsu Microelectronics Co., Huajin } \\
\text { Electronics Group Corp., Toshiba Hydro } \\
\text { Power (Hangzhou) Co., Ltd., TCL Corp. }\end{array}$ \\
\hline LG & $\begin{array}{l}\text { Geely Automobile Holdings Ltd., Huayou } \\
\text { Cobalt, Gansu Province Electric Power } \\
\text { Investment Group Co., Ltd (GEPIC) China } \\
\text { National Offshore Oil Corp (CNOOC) }\end{array}$ \\
\hline HP & Tsinghua Holdings \\
\hline Panasonic & $\begin{array}{l}\text { Chinese company Friday, Dalian Levear } \\
\text { Electric Co., Ltd., Beijing Matsushita Color } \\
\text { CRT (China Government) }\end{array}$ \\
\hline Sony & Shanghai Oriental Pearl \\
\hline Dell & Kingsoft \\
\hline Microsoft & $\begin{array}{l}\text { Beijing Centergate Technologies (Holding) } \\
\text { Co., Ltd. (CENTEK), China Electronics } \\
\text { Technology Group, Shanghai Alliance } \\
\text { Investment Co. Ltd. }\end{array}$ \\
\hline Samsung & Shanghai Bell Co, Kerry Logistics. \\
\hline
\end{tabular}

Source: Jing (2017), Xinhua News Agency (2002), CNBC (2018), Judge (2015), Shepard (2016), EETimes (2001), Fujitsu (2018), The Japan Times (2009), Microsoft (2002), Seric and Yee (2019), Panasonic (n.d.), Reuters (2019), South China Morning Post (2010), Sony (2020), Toshiba (2020), Yonhap News Agency (2017), Cho (2018). 
Reimaging Post COVID-19 Global Value Chain:

Case Study of Automotive and Electronic Companies in China

Most automotive companies use the same strategy. Many large automotive manufacturers have joint ventures with local automotive companies, as can be seen in the following table (Dunne 2012):

Table 2.

Foreign auto manufacturer on a joint venture with China's company

\begin{tabular}{|c|c|}
\hline $\begin{array}{l}\text { Foreign Auto } \\
\text { Manufacturer }\end{array}$ & Joint Ventures (with) \\
\hline BMW & $\begin{array}{l}\text { Brilliance Auto (BMW-Brilliance), BAIC } \\
\text { (BAIC-BMW) }\end{array}$ \\
\hline Fiat & $\begin{array}{l}\text { GAC Fiat Chrysler, BAIC (BAIC FCA } \\
\text { Automobile Co. Ltd) }\end{array}$ \\
\hline Ford & Changan Ford FAW \\
\hline General Motors (GM) & $\begin{array}{l}\text { SAIC, FAW, GAC (GAC Chevrolet Opel } \\
\text { Motors Co.Ltd) }\end{array}$ \\
\hline Honda & $\begin{array}{l}\text { GAC (Guangqi Honda), Dongfeng Motor } \\
\text { Group (Dongfeng Honda) }\end{array}$ \\
\hline Hyundai & $\begin{array}{l}\text { BAIC, Great Wall (Great Wall-Hyundai } \\
\text { Motors Co.Ltd) }\end{array}$ \\
\hline Jaguar Land Rover & Chery (Chery Jaguar Land Rover) \\
\hline Kia & $\begin{array}{l}\text { Dongfeng Motor Corporation (Dongfeng } \\
\text { Yueda Kia) GAC (GAC Hafei Kia Motors Co } \\
\text { Ltd.) }\end{array}$ \\
\hline Mazda & FAW, Changan \\
\hline Mercedes-Benz & BAIC (Beijing-Benz), BYD (Denza) \\
\hline Mitsubishi & Soueast, GAC (GAC-Mitsubishi) \\
\hline Nissan & $\begin{array}{l}\text { Dongfeng Motor Group (Dongfeng Motor } \\
\text { Co., Ltd.), BAIC Group (BAIC Nissan) }\end{array}$ \\
\hline Peugeot & $\begin{array}{l}\text { Dongfeng Motor Group, Great.Wall (Great } \\
\text { Wall Peugeot Citroën Co. Ltd) }\end{array}$ \\
\hline Renault & $\begin{array}{l}\text { Dongfeng Motor Group, FAW (FAW Renault } \\
\text { Nissan Motors Co. Ltd) }\end{array}$ \\
\hline Suzuki & Changan, Dongfeng Motor Group \\
\hline Toyota & GAC (GAC-Toyota), FAW \\
\hline
\end{tabular}




\begin{tabular}{|l|l|}
\hline Volkswagen & SAIC, FAW (FAW-Volkswagen), GAC \\
\hline Isuzu & JMCG, JIM, GAC \\
\hline
\end{tabular}

Source: Dunne (2012)

It is noticeable that most companies use joint ventures as their strategy before the pandemic because it is also supported by the implementation of the "Law of Sino-Foreign Joint Venture" policy. Thus, these companies combine their capital, know-how, assets, other resources and form an alliance with local companies in China for the long term. These companies rely on their operations, decision-making, profits, and leadership of the local partner through this strategy. It is apparent that various electronic and automotive companies still entrust production centers for main products and their supporting products in China. In this case, these electronics and automotive companies have succeeded in establishing strategic alliances with the Chinese government and local companies through a joint venture strategy.

\section{Actors'Strategies and Regulation in China After COVID-19}

The COVID-19 pandemic that emerged in China at the end of 2019 significantly impacted the economic order in various parts of the world, including in the GVC sector (Gopinath 2020; OECD 2020). As the first country to report COVID-19 cases, China became the first to implement a lockdown policy. In January 2020, the Chinese government decided to close at least 13 cities in Hubei province, where the SarsCov-2 virus was alleged to have originated (Leung 2020). Mistreanu (2020) stated that the Chinese government has indeed instructed to close various industrial activities in most provinces in China in January 2020 and is planned to reopen ten days after the Chinese New Year on 9 February 2020. However, up to two weeks after that date, the government still has not issued a policy that allows industrial activities to resume operations as in normal situations.

The lockdown policy and the restrictive policy related to the movement of goods seriously impact the highly complex and globally integrated supply chain industrial sectors. Thus, various electronics and automotive companies experienced 
severe GVC disruptions, especially in the supply chain sector. Besides production and logistical problems, the highly complex and globally integrated supply chain industry, especially the automotive industry, also experienced value chain disruption caused by the COVID-19 pandemic in the marketing sector. As Tajitsu and Shiraki (2020) stated, the losses suffered by Japanese car manufacturers came from the production and logistical sector and the marketing sector. In February 2020, the sales of the three leading Japanese car brands in China decreased by $85 \%$ compared to the previous period. Not only car OEM companies such as Toyota, Honda, Nissan, and Mazda, tier 1 and 2 supplier companies are also experiencing similar problems. According to Tajitsu and Shiraki (2020), there are at least three supplier companies, including Koito, the world's largest manufacturer of car front and rear LED lights, and a tier 1 supplier for Toyota and Nissan. The company's production was disrupted because its factory in Hubei was closed, which hampered the supply chain for its car lamps. Then two other companies that experienced the same thing were Mazda's spare parts supplier and Kasai Kogyo, a supplier company for interior doors and roofs for Honda cars.

A similar impact was experienced by South Korean car manufacturer, Hyundai, where the brand was the first major automotive brand that decided to delay its production in South Korea due to a shortage of spare parts imported from China. Not much different, European automotive manufacturers have also been affected by the COVID-19 pandemic. For example, the leading Italian manufacturer, Fiat, has also postponed its production in Italy due to a shortage of spare parts from China. On the other hand, the leading German automotive manufacturers, namely VW, Mercedes Benz, and BMW, also stated that the COVID-19 pandemic caused enormous losses for them. It should be noted that $40 \%$ of VW cars marketed worldwide are made in China, while $30 \%$ of all Mercedes Benz and BMW units circulating worldwide are made in China.

Although the three companies do not have a production center or supply chain directly connected to Hubei, the three companies are also disadvantaged due to lockdown policies and industrial closures because the productivity of the three companies has 
decreased. In addition, VW, Mercedes Benz, and BMW have positioned China as a manufacturing center in its GVC and as one of the leading marketing targets for their products. However, the social restriction policies and the uncertain situation caused by the pandemic made many people avoid non-essential public places and made not many people prioritize buying a car. Hence, the showrooms of the three companies became quiet, and sales decreased significantly (DW 2020).

Based on the explanation, it can be seen that the Chinese government's policies to deal with unexpected situations, namely the COVID-19 pandemic, also harmed the practice of GVC fragmentation, especially in the highly complex and globally integrated supply chain industrial sector such as electronic and automotive products. As a result, the value chain from production to marketing phase experienced a very detrimental disruption. Furthermore, as stated in Patel-Campilo (2010), government policy also determines the governance of GVC in a country. In this case, changes in government policy, namely the implementation of lockdowns and restrictions on the movement of people and goods, have disrupted the GVC governance in China. As a result, this situation has demonstrated the weakness of the fragmentation in the GVC system, which is susceptible to unexpected situations that occur on a large scale.

This situation leaves the various companies affected with not many strategic options. However, several companies have tried to rearrange their strategies and rethink their strategic alliance to save themselves from disruption. For example, Koito, a supplier of car lamps for Toyota and Nissan, decided to move their factories from China, but it has not been stated where the company will move. Meanwhile, Kasai Kogyo, supplier of interior doors and roofs for Honda, has decided to move production from Wuhan to Europe and North America. Not much different, Mazda spare parts suppliers operating in Jiangsu, China, shifted production to Guanajuato, Mexico (Tajitsu and Shiraki 2020). Suzuki is also doing the same thing (BBC 2020). This strategy is taken to overcome the chaos in value chain management in China due to the COVID-19 pandemic that first broke out in the country (Tajitsu and Shiraki, 2020). 


\section{Reimaging Post COVID-19 Global Value Chain: Case Study of Automotive and Electronic Companies in China}

Although challenges in the production sector can be handled with a strategy referred by Tajitsu and Shiraki (2020) as "shifting away from epicentrum" ${ }^{11}$, challenges in the sales sector are still visible. It can be seen from VW, Mercedes Benz, and BMW, who have made their utmost efforts to rearrange their marketing strategies. The three leading companies make their determined attempts in presenting and promoting online showrooms to increase purchases. However, these efforts were unsuccessful. Even though they had presented a breakthrough through an online showroom, their sales number still did not experience a significant increase (DW 2020).

In line with the strategy, the Japanese government provides attractive offers for Japanese companies with a GVC network in Chinaby providing incentives and subsidies for Japanese companies who are willing to move their production activities out of China, especially to Japan. Furthermore, the Japanese government took this step to secure the GVC of Japanese companies experiencing uncertainty due to the pandemic situation in China (Tsuji and Furuyama 2020). With this step, the Japanese government tried to influence Japanese MNCs to rethink its strategy and make the Japanese government a strategic alliance to create more robust and more stable GVC governance.

From the country level, the obstruction of GVC fragmentation due to the pandemic situation in China is apparent in the drop of China's industrial output in the first two months of 2020. During that period, China's industrial output fell by $13.5 \%$ from the previous period. It was also accompanied by a significant drop in the level of China's exports. As a result, this condition triggers many multinational companies to move their production activities from China. However, we find that the COVID-19 pandemic is not the main factor driving various MNCs to leave China. There are predecessor factors, namely the limited availability of Chinese workers due to too many companies operating in China, the large number of Chinese citizens who have migrated, and the one-child policy implemented by the Chinese government. Those factors can potentially eliminate China's comparative advantages, namely

1 Shifting away from epicentrum is a strategy applied by some Japanese automotive manufacture to move its production center away from China as the pandemic epicentrum. 
large amounts of cheap labor (Loyalka 2012; Shepard 2020).

The various disruptions caused by the COVID-19 pandemic have exposed "weaknesses" or "fault lines" in the fragmented GVC system (Strange 2020; McCausland 2020). It means that a globally interconnected GVC is vulnerable to shock effects caused by global events. As a result of these disruptions, various companies and countries are experiencing shortages of their raw materials. It happened because of the cessation of production in countries affected by the pandemic, limited access, and export-import discrimination, and many companies, which in normal situations would have been the leading suppliers for these companies, now prefer domestic consumers (Strange 2020). The severity of the impact of COVID-19 on fragmented GVCs is also indicated by the trend of companies "withdrawing" from the fragmented GVC network, or in other words, reshoring. The point is, companies that previously set up industrial facilities in other countries moved these facilities into their own countries, then companies that initially relied on supply chains from other countries began to switch to domestic supplies (Maul 2020). Based on data obtained by the Thomas Survey in April 2020 (in McCausland 2020), 64\% of the 878 companies from North America scattered around the world decided to conduct reshoring due to the difficulties and uncertainties caused by the great lockdown amidst the COVID-19 pandemic. In addition, the COVID-19 pandemic has also resulted in the bankruptcy of various companies in the world. In the United States alone, there have been 330 companies that have declared bankruptcy due to COVID-19 this year. These numbers are dominated by companies that rely on GVCs, such as companies in the energy sector (Scigliuzzo et al. 2020).

\section{The Relevance of Fragmented GVC in the Post COVID-19 Era}

Lockdown policy has hampered production activities and disrupted GVC fragmentation in the world. These obstacles forced a directional shift in the GVC, from fragmentation back to vertical integration to respond to the pandemic and restrictive policies. It 
can be seen from the trend of companies considering "withdrawing" from the fragmented GVC network and returning to 'nationalizing' their production processes. The COVID-19 pandemic has opened our eyes to how fragile the fragmented system is, based on the conditions of interdependence between companies and suppliers worldwide.

Until December 2020, the COVID-19 pandemic is still full of uncertainty about when it will actually end (WHO 2020). Nevertheless, there was positive growth in the automotive sector in China as of December 2020, particularly in car production and sales. It is due to the strong support from Chinese government policies, the efforts of industrial companies, and the strong recovery in consumer demand (Jie 2021). China successfully raised its vehicle sales for nine consecutive months by the end of December even though sales fell for the first quarter of 2020, making the country leading in the global auto industry's recovery from the COVID-19 pandemic. In early 2020, the automotive industry in China was hit hard by the pandemic. However, it started to bounce back during the second quarter along with the rest of the economy as the country managed to control the outbreak. As a result, automotive companies in China reported sales growth in 2020, including Toyota and Great Wall Motor (Reuters 2021). Despite the resilience of the automotive industry in China because the economic activity and GDP are starting to recover, businesses are starting to reopen, and the social distancing of people continues, China is still fighting against the pandemic. Therefore, both citizens and the government of China need to find paths to fight the virus collectively and protect their lives and livelihoods (BCG 2020).

There has been positive progress in handling the COVID-19 pandemic and the recovery of the industrial sectors, especially the automotive industry in China. However, as has been done by many companies globally, reshoring options are the most feasible to do during a pandemic. In addition, the fact is that tasks related to the production process such as research and development, design, marketing and branding, and other tasks that require resources with certain capabilities are still carried out at the head office or the company's country of origin. This condition will undoubtedly be one of the driving factors for many companies to nationalize 
their production activities. In the offshore case, the company will pay close attention to the comparative advantages owned by the country, which will serve as a production center (Chen in Greffi and Korzeniewicz 1994; Gereffi et al. 2005).

However, reshoring also has its negative impacts. First, to restore the initial problems companies face, the high cost of carrying out the production process. This problem can be overcome with automation, but automation cannot be done quickly, especially if the company is in a developing country where technology is still a common homework. Second, in their research, Bonadio et al. (2020) project that there will be a reduction in state income, making GDP contraction worse with the nationalization of the production process. Christine Arriola et al. (2020) also stated that the nationalization of the production process is projected to significantly result in lower income levels of economic activity and the potential to reduce the real global GDP by more than $5 \%$ compared to the baseline estimated post-COVID-19. This projection is based on the fact that the nationalization of the production process involves a lot of input along the value chain, which is usually less available and more expensive. Another thing is that if high capital investment is necessary, the state must also provide support to companies when the demand is shrinking or when local production is not competitive. This condition makes the reshoring policy considered not to provide the efficiency or security of supply as expected.

Meanwhile, the fragmented system provides attractive benefits for industrial actors because of its low production costs. This benefit makes the probability of the fragmented GVC option chosen by many companies worldwide after the COVID-19 pandemic is still high. Given that the fragmented system can provide the greatest cost efficiency and benefits until now, it is not strange that this system will remain an option for many business people in the world when the great lockdown due to the COVID-19 pandemic is no longer an obstacle. Even so, they need to consider the impact of the pandemic on the production process. If the pandemic hampers the production process in fragmented GVC, it can cause huge losses and make this system no longer relevant to be used when similar disasters as pandemic COVID-19 happen in the future. 
Both fragmentation and reshoring have their respective impacts and risks during the COVID-19 pandemic, especially for the automotive and electronic sectors. However, these two options will not be an absolute choice for the companies in the world. In response to the pandemic, companies still have to take a good stance on fragmentation, reshoring, and other options. Apart from considering the sustainability of the production process, the decisions taken must also consider consumer behavior, as previously discussed. Because in the end, the production process will still depend on consumer demand in the market. Decisions will be taken according to each company's sectors, considerations, and state support. However, the potential negative impacts that may arise must be considered and managed. Thus, any system used to run the production process will be more resistant to the shocks that can occur at any time and affect the GVC.

\section{Conclusion}

The global pandemic has harmed the fragmented GVC system. This condition occurred because the policies to restrict the mobility of people and goods during the pandemic in various countries, especially China, hamper the production activities and cut off the supply chain network that supports the production. As a result, the productivity of companies that rely on supplies from various countries has decreased significantly. A historical examination of GVC in China showed a change from a vertically integrated production system to a fragmented GVC due to its benefit. China became one of the important links in fragmented GVC for electronics and automotive companies worldwide due to its open policy regarding FDI, the availability of cheap labor in large numbers, possible industrial facilities, and a very potential domestic market. However, when the COVID-19 pandemic hit, automotive and electronics companies that used the fragmented GVC system in China suffered a loss due to the disruption of the production process by lockdown policy and were forced to face the uncertain situation. The examination on actor's strategies and regulations of GVC in China shows a change in the strategy of industrial actors, especially the automotive and electronics 
sectors. It shifted from the joint venture strategy that was chosen by most automotive and electronic companies to "withdrawing" from the fragmented GVC network in China due to the COVID-19 pandemic, which also exposed the "weaknesses" or "fault lines" in the system of fragmented GVC.

Therefore, fragmented GVC in the post-COVID-19 era in China for the automotive and electronic companies is still relevant. As the fragmented system provides the greatest cost efficiency and benefits, this system will remain an option for many business people in the post-pandemic world. However, modifications are still necessary to make this system more reliable when faced with a similar situation in the future. Moreover, the reshoring system done by many companies globally is the most feasible during a pandemic that poses the least risk to the company and is more resistant to external shocks such as the ongoing pandemic. After all, the system chosen by the automotive and electronic companies in China should consider the sustainability of the production process, consumer behavior, and potential negative impacts must be considered and prepared to prevent disruption that may occur as the pandemic on the GVC's production process.

\section{References}

\section{Books and Chapter in Books}

Abbott, A., 1997. "On the Concept of Turning Point" in Brochman, G., etal.(eds.), 1997. Methodological Issues in Comparative Social Sciences. Greenwich, CT: JAI Press.

Gereffi, Gary, and Miguel Korzeniewicz (eds.), M. 1994. Commodity Chains aAnd Global Capitalism. Westport: Preager Publisher.

Negara, Siwage Dharma, 2010. "Fragmentation of electronics and textile industries from Indonesia to CLMV countries" in Banomyong, R. and M. Ishida (eds.), A Study on Upgrading Industrial Structure of CLMV Countries. ERIA Research Project Report 2009-7-3, Jakarta: ERIA. 
Reimaging Post COVID-19 Global Value Chain:

Case Study of Automotive and Electronic Companies in China

Steger, Manfred B., 2003. "The Economic Dimension of Globalization” in Globalization: A Very Short Introduction. Oxford: Oxford University Press.

\section{Journal Articles}

Arndt, S.W., 1997. "Globalization and the open economy", The North American Journal of Economics and Finance, 8 (1): 71-79.

Blanchard, Jean-Marc F., 2007. "China, Multinational Corporations, And Globalization: Beijing and Microsoft Battle Over The Opening Of China's Gates", Asian Perspective, 31 (3): 67-102.

David, P.A., 1985. "Clio and the Economics of QUERTY", American Economic Review, 75 (2): 332-337.

Gereffi, Gary, et al., 2005. "The Governance of Global Value Chains", Review of International Political Economy, 12 (1): 78-104.

Hayakawa, Kazunobu, and Hiroshi Mukunoki, 2021. "Impacts of COVID-19 on Global Value Chains", The Developing Economies, 59 (2): 154-177.

Kogut, B. 1985. "Designing Global Strategies: Comparative and Competitive Value-Added Chains", Sloan Management Review, 26 (4): 15-28.

Los, Bart, et al., 2015. "How global are global value chains? A new approach to measure international fragmentation", Journal of regional science, 55 (1): 66-92.

Mahoney, James, 200o. "Path Dependence in Historical Sociology", Theory and Society, 29 (4): 507-548.

McCausland, Tammy, 2020. “COVID-19's Impact on Globalization and Innovation", Research-Technology Management, 63 (6): 54-59.

Mehta, Seema, et al., 2020. "The New Consumer Behaviour Paradigm amid COVID-19: Permanent or Transient?”, Journal of Health Management, 22 (2): 291-301. 
Patel-Campillo, A., 2011. "Transforming global commodity chains: Actor strategies, regulation, and competitive relations in the Dutch cut flower sector", Economic Geography, 87 (1): 79-99.

Strange, Roger, 2020. "The 2020 Covid-19 pandemic and global value chains", Journal of Industrial and Business Economics, 47: 455-465.

Zhang, Kevin H., 2001. "What Attracts Foreign Multinational Corporations to China?", Contemporary Economic Policy, 19 (3): 336-346.

\section{Online Articles}

Amatech, 2021. "OEMs, Tier 1, 2 \& 3 - The Automotive Industry Supply Chain Explained" [online]. in https:// www.amatechinc.com/resources/blog/returnablepackaging/tier-1-2-3-automotive-industry-supplychain-explained \#: : text=Tier\% 201\%2C\%202\%20 and $\% 203$,or $\% 20$ systems $\% 2$ odirectly $\% 2$ oto $\% 20$ OEMs.\&text $=$ Tier\% $202 \% 20$ suppliers\% 20 are $\% 20$ often,to\%2oproduce\%20automotive\%2Dgrade\%2oparts [Accessed on 6 March 2021].

Barboza, David, 2021. “An iPhone's Journey, From the Factory Floor to the Retail Store" [online]. in https://www.nytimes. com/2016/12/29/technology/iphone-china-apple-stores. html [Accessed on 21 February 2021].

BBC, 2020. "Coronavirus: The world in lockdown in maps and charts", 7 April [online]. in_https://www.bbc.com/news/ world-52103747 [Accessed on 14 December 2020].

BCG. 2020. COVID-19's Impact on the Automotive Industry. https://www.bcg.com/publications/2020/covidautomotive-industry-forecasting-scenarios. [Accessed on 12 March 2021].

Bertasiute, A., et al., 2020. "Deglobalisation post COVID-19 could spell trouble for the European Monetary Union" [online]. in https://blogs.lse.ac.uk/businessreview/2020/07/01/ deglobalisation-post-covid-19-could-spell-trouble-for- 
Reimaging Post COVID-19 Global Value Chain:

Case Study of Automotive and Electronic Companies in China

the-european-monetary-union/ [Accessed on 14 December 2020]

Bonadio, B., et al. 2020. "The Role of Global Supply Chains in the COVID-19 Pandemic and Beyond", VoxEU CEPR, 25 May [online]. in https://voxeu.org/article/role-global-supplychains-covid-19-pandemic-and-beyond [accessed on 24 September 2021].

China Daily, 2020. "China is the world's factory, more than ever: The Economist", 29 June [online]. https://global.chinadaily. com.cn/a/202006/29/WS5ef9ae36a310834817255e58. html [Accessed on 6 March 2021].

Cho, Mu-Hyun, 2018. "LG Chem forms joint ventures in China for EV battery production”, Zdnet, 11 April [online]. in https:// www.zdnet.com/article/lg-chem-forms-joint-ventures-inchina-for-ev-battery-production/ [Accessed on 9 March 2021].

CNBC, 2018. "Apple moves to store iCloud keys in China, raising human rights fears", 24 February [online]. in https://www. cnbc.com/2018/02/24/apple-moves-to-store-icloudkeys-in-china-raising-human-rights-fears.html [Accessed on 22 April 2020]

Collins, Jimmy, 2020. “Apple’s Supply Chain Is aAt Risk From The Coronavirus", Forbes, 29 January, [online]. in https://www.forbes.com/sites/jimcollins/2020/01/29/ apples-supply-chain-is - at - risk-from-thecoronavirus/?sh=2dboa07867c1 [Accessed on 18 February 2021].

Dunne, Michael, 2012. "Chinese Auto Makers: Joint-Venture Junkies?”, The Wall Street Journal, 10 September [online]. in https://www.wsj.com/articles/BL-CJB-16462 [Accessed on 16 February 2021].

DW, 2020. "China Coronavirus Adds tTo German Automakers'Automakers' Woes” [online]. in https:// www.dw.com/en/china-coronavirus-adds-to-germanautomakers-woes/a-52366651 [Accessed on 6 March 2021]. 
EETimes, 2001. "Samsung forms CDMA joint venture in China", 26 November [online]. in. https://www.eetimes.com/ samsung-forms-cdma-joint-venture-in-china/\# [Accessed on 22 April 2021].

Facts and Details, 2012. "Foreign Companies And Foreign Investment In China" [online]. in http://factsanddetails. com/china/cat9/sub62/item349.html [Accessed on 18 February 2021].

Fujitsu, 2018. "Fujitsu and INESA Establish Joint Venture to Develop the Smart Manufacturing Market in China", 9 March [online]. in https://www.fujitsu.com/global/ about/resources/news/press-releases/2018/0309-01. html [Accessed on 9 March 2021].

Gopinath, Gita, 2020. "The Great Lockdown: Worst Economic Downturn Since the Great Depression”, IMF Blog, 14 April [online]. in https://blogs.imf.org/2020/04/14/the-greatlockdown-worst-economic-downturn-since-the-greatdepression/ [Accessed on 14 December 2020].

Gurman, Mark, and Debby Wu, 2020. "Apple Supply Chain Braces for Disruption Fromfrom Coronavirus", Bloomberg, 28 January [online]. in https://www.bloomberg.com/news/ articles/2020-01-28/apple-supply-chain-braces-fordisruption-from-coronavirus [Accessed on 18 February 2021].

Hara, Yoshihiro, 2020. "Honda and Toyota to keep Chinese plants closed over virus fears", Nikkei Asia, 7 February [online]. in https://asia.nikkei.com/Spotlight/Coronavirus/ Honda-and-Toyota-to-keep-Chinese-plants-closed-overvirus-fears. [Accessed on 18 February 2021].

Indonesian Ministry of Finance. 2020. "Restrictions on the Movement of Goods and People during the Pandemic Affect Export and Import Performance in May 2020" [online]. in https://www.kemenkeu.go.id/en/publications/ news/restrictions-on-the-movement-of-goods-andpeople-during-the-pandemic-affect-export-and-importperformance-in-may-2020/ [Accessed on 14 December 2020]. 
Reimaging Post COVID-19 Global Value Chain:

Case Study of Automotive and Electronic Companies in China

International Transport Forum, 2020. "COVID-19 Transport Brief”, 11 May [online]. in https://www.itf-oecd.org/sites/ default/files/global-freight-covid-19.pdf [Accessed on 18 December 2020].

Investopedia, 20210. "How many multinational corporations operate in China?", 13 August [online]. in https://www. investopedia.com/ask/answers/021015/how-manymultinational-corporations-operate-china.asp. [Accessed on 16 February 2021].

Jing, Shi, 2017. "Gaming Giants on the Winning Track", China Daily, 21 June [online]. in. https://www.chinadaily. com.cn/business/2017-06/21/content_29825940.htm. [Accessed on 22 April 2020].

Judge, Peter, 2015. “Dell announces \$125bn China plan: Joint venture with Kingsoft is part of "In China, For China" strategy" [online]. in https://www.datacenterdynamics. com/en/news/dell-announces-125bn-china-plan/. [Accessed on 22 April 2020].

Kim, Heung Chong, 2020. "Deglobalization, Global Value Chains, and International Cooperation in a Time of Defragmentation" Valdai Discussion Club, 10 November [online]. in https://valdaiclub.com/a/highlights/ deglobalization-global-value-chains/. [Accessed on 14 December 2020].

Lawder, David, 2020. "Coronavirus' Coronavirus 'Great Lockdown” to shrink global economy by $3 \%$ in 2020: IMF” The Jakarta Post, 14 April. [online]. in https://www.thejakartapost. com/news/2020/04/14/coronavirus-great-lockdown-toshrink-global-economy-by-3-in-2020-imf.html. [Accessed on 14 December 2020].

Leung, Hillary, 2020. "China Puts 13 Cities on Lockdown as Coronavirus Death Toll Climbs” Time, 24 January [online]. in https://time.com/5770801/china-wuhan-coronavirusspread-world-health-organization/. [Accessed on 18 February 2021].

Li, Lauly, and Cheng Ting-Fang, C. 2021. "Apple ramps up iPhone and iPad output shift to India and Vietnam", Nikkei Asia, 27 January [online]. in https://asia.nikkei.com/Economy/ 
Trade-war/Apple-ramps-up-iPhone-and-iPad-outputshift-to-India-and-Vietnam. [Accessed on 21 April 2021].

Limenta, Michelle, 2020. "Rising Export Protectionism in Time of Global Isolation", The Jakarta Post, 28 April [online]. in https://www.thejakartapost.com/ academia/2020/o4/28/rising-export-protectionism-intime-of-global-isolation.html. [Accessed on 14 December 2020].

Loyalka, Michelle D., 2012. "Chinese Labor, Cheap No More", The New York Times, 18 February [online]. in https://www. nytimes.com/2012/02/18/opinion/chinese-labor-cheapno-more.html. [Accessed on 7 March 2020].

Maul, Steve, 2020. "Reshoring: COVID-19's Impact on the Supply Chain", Supply Chain Management Review, 10 June [online]. in https://www.scmr.com/article/reshoring covid_19s_impact_on_the_supply_chain. [Accessed on 14 December 2020].

Microsoft, 2002. "Microsoft Announces its First Software Joint Venture in China", 16 January [online]. in https://news. microsoft.com/2002/01/16/microsoft-announces-itsfirst-software-joint-venture-in-china/ [Accessed on 21 April 2021].

Mistreanu, Simina, 2020. "China'sChina's Factories Are Reeling From Forced Coronavirus Closures", Forbes, 23 February [online]. in_https://www.forbes. $\mathrm{com} /$ sites/siminamistreanu/2020/02/23/chinasfactories-are-reeling-from-forced-coronavirusclosures/?sh=482ea85573f2. [Accessed on 18 February 2021].

Panasonic, n.d. "Joint venture company with Beijing established" [online]. in https://www.panasonic.com/global/ corporate/history/chronicle/1987.html [Accessed on 21 April 2021].

Preen, Mark, 2019. "Economic Reform in China: Current Progress and Future Prospects", China Briefing, 3 April [online]. in https://www.china-briefing.com/news/economic-reform- 
Reimaging Post COVID-19 Global Value Chain:

Case Study of Automotive and Electronic Companies in China

china-opening-up-future-prospects/ [Accessed on 16 February 2021].

Rapoza, Kenneth, 2020. "Coronavirus Could BeTheEnd OfChinaAs A Global Manufacturing Hub", Forbes, 1 March [online]. in https://www.forbes.com/sites/kenrapoza/2020/03/o1/ coronavirus-could-be-the-end-of-china-as-globalmanufacturing-hub/?sh=78c5d2ab5298 [Accessed on 14 December 2020].

Reuters, 2019. "South Korea's LG Chem to team up with China's Geely on EV batteries", 13 June [online]. in https:// www.reuters.com/article/us-lg-chem-geely-automobilejointventure-idUKKCN1TD2XG [Accessed on 9 March 2021].

Reuters, 2021. "Chinese auto recovery on track as vehicle sales rise for ninth month", 13 January [online]. in https:// www.reuters.com/world/china/china-auto-sales-headrebound-this-year-2-fall-2020-2021-01-13/ [Accessed on 9 March 2021].

Rogoff, Kenneth, 2020. "Deglobalisation will hurt growth everywhere", The Guardian, 4 June [online]. in https:// www.theguardian.com/business/2020/jun/o4/ deglobalisation-will-hurt-growth-everywhere [Accessed on 14 December 2020].

Scigliuzzo, Davide, et al., 2020. "The Covid Bankruptcies: Guitar Center to Helicopter Charters", Bloomberg, 9 July [online]. in https://www.bloomberg.com/graphics/2020us-bankruptcies-coronavirus/ [Accessed on 14 December 2020].

Seckin, Baris, 2020. "Italy stops unnecessary production amid pandemic",Anadolu Agency, 22 March [online]. in https:// www.aa.com.tr/en/europe/italy-stops-unnecessaryproduction-amid-pandemic-/1774567. [Accessed on 14 December 2020].

Seric, Adnan, and Yee Siong Tong, 2019. "What are Global Value Chains and Why do They Matter?" IAP UNIDO, [online]. 
in https://iap.unido.org/articles/what-are-global-valuechains-and-why-do-they-matter [Accessed on 9 March 2021].

Shedletsky, Anna-Katrina, 2019. "Made In China? Three Trends Driving Electronics Manufacturing In 2019", Forbes, 24 January [online]. in_https://www.forbes. com/sites/annashedletsky/2019/o1/24/made-in-chinathree-trends-driving-electronics-manufacturing-in2019/?sh=fabf6f29039f [Accessed on 18 February 2021].

Shepard, Jeff, 2016. "Panasonic and Dalian JV to make Automotive Batteries in China", EEPower, 7 February [online]. in https://eepower.com/news/panasonic-and-dalian-jv-tomake-automotive-batteries-in-china/\# [Accessed on 22 April 2021].

Shepard, Wade, 2020. "COVID-19 Undermines China's Run As The World's Factory, But Beijing Has A Plan”, Forbes, 26 March [online]. in https://www.forbes.com/sites/ wadeshepard/2020/03/26/covid-19-undermines-chinasrun-as-the-worlds-factory-but-beijing-has-a-plan/amp/ [Accessed on 7 March 2020].

Sony, 2020. "Statement Regarding the Impact of the Spread of the Novel Coronavirus", 27 March [online]. in https:// www.sony.net/SonyInfo/News/Press/202003/20-023E/ [Accessed on 9 March 2021].

South China Morning Post, 2010. "Toshiba forms joint venture with TCL to expand flat-panel TV sales in the mainland", 16 July [online]. in. https://www.scmp.com/article/719803/ toshiba-forms-joint-venture-tcl-expand-flat-panel-tvsales-mainland [Accessed on 9 March 2021].

Statista, 2021. "Number of Novel Coronavirus COVID-19 Cumulative Confirmed and Death Cases in China from January 20, 2020 to September 19, 2021" [online]. in https://www.statista.com/statistics/1092918/chinawuhan-coronavirus-2019ncov-confirmed-and-deceasednumber/ [Accessed on 9 March 2021]. 
Reimaging Post COVID-19 Global Value Chain:

Case Study of Automotive and Electronic Companies in China

Tajitsu, Naomi and Maki Shiraki, 2020. "Now Made In Mexico: Japan Auto Suppliers Shift China Production After Coronavirus", Reuters, 16 March [online]. in https://www. reuters.com/article/health-coronavirus-japan-autosidUSL5N2ARoHF [Accessed on 18 February 2021].

The Japan Times, 2009. "Toshiba to cut costs with China JV", 21 November [online]. in. https://www.japantimes.co.jp/ news/2009/11/21/business/toshiba-to-cut-costs-withchina-jv/ [Accessed on 9 March 2021].

Toshiba, n.d. "Company Profile" [online]. in. http://en.toshibathpc.com/comcontent_detail/\&FrontComContent_ list01-1344407007942CurrentIds $=6$ __19\&comConten tId=19\&comp_stats =comp-FrontComContent_listo11344407007942.html [Accessed on 9 March 2021].

Tsuji, T \& Furuyama, K. 2020. Japan preps first subsidy to company moving production out of China. https://asia.nikkei.com/ Spotlight/Coronavirus/Japan-preps-first-subsidy-tocompany-moving-production-out-of-China. [Accessed on 9 March 2021].

Wei, He, et al., 2019. "China's Giant Domestic Market Seen As Bulwark Amid Global Economic Woes", China Daily, 4 October [online]. in. https://www.chinadaily.com. cn/a/201910/o4/WS5d9631baa310cf3e3556eb5o.html [Accessed on 18 February 2021].

WHO, 2020. "WHO Coronavirus Disease (COVID-19) Dashboard" [online]. in https://covid19.who.int/ [Accessed on 14 December 2020].

World Bank, 2020. "Most Commodity Prices to Drop in 2020 As Coronavirus Depresses Demand and Disrupts Supply" [online]. in https://www.worldbank.org/en/news/pressrelease/2020/04/23/most-commodity-prices-to-drop-in2020-as-coronavirus-depresses-demand-and-disruptssupply [Accessed on 14 December 2020].

Xinhua News Agency, 2002. "Microsoft Launches Fist Joint Venture in China" [online]. in. http://www.china.org.cn/ 
english/investment/30614.htm [ Accessed on 22 April 2020].

Yilei, Feng, et al., 2019. "BMW Brilliance Auto Helps Chinese Car Manufacturing Suppliers Become World-Class". CGTN, 17 September[online].in https://news.cgtn.com/news/2019o9-17/BMW-helps-Chinese-car-manufacturing-suppliersbecome-world-class-K4fXtZ703e/index.html [Accessed on 16 February 2021].

Yonhap News Agency, 2017. "Samsung SDS establishes joint venture with Chinese firm", 16 May [online]. in https:// en.yna.co.kr/view/AEN20170516003800320 [Accessed on 22 April 2021].

Zhang, Thomas, 2020. "Global Automobile Supply Chains Will Survive Despite COVID-19 Disruption”, CGTN, 9 April [online]. in https://news.cgtn.com/news/202004-09/Global-carmaking-supply-chains-to-survivedespite-COVID-19-disruption-PxQqV3rK3m/index.html [Accessed on 18 February 2021].

\section{Others}

Baldwin, Richard and Javier Lopez Gonzalez, 2013. "Supply-Chain Trade: A Portrait of Global Patterns and Several Testable Hypotheses", CEPR Discussion Paper No. DP9421, 16 April.

Christine, A. et. al. 2020. "Efficiency and Risks in Global Value Chains in the Context of Covid-19", Economics Department Working Papers No. 1637. OECD.

Coffin, David. 2019. "China's Growing Role in U.S. Automotive Supply Chains", Office of Industries Working Paper ID060, August.

Debanes, P., 2018. "Modes of Insertion into Global Value Chains as a Source of Firms' Heterogeneity?: Evidence from a Panel of Korean Manufacturing Firms 1990-2015”. Halshs- 
Reimaging Post COVID-19 Global Value Chain:

Case Study of Automotive and Electronic Companies in China

01849224f.

Jones, Ronald W.A., 200o. "Framework for Fragmentation No. oo-056/2", Tinbergen Institute Discussion Paper.

Jie, G. 2021. China's Industrial Economy in 20201. https://english. ckgsb.edu.cn/wp-content/uploads/2021/03/2020Q4report-short-English-Jie.pdf. [Accessed on 22 April 2021]

OECD, 2020. "COVID-19 and Global Value Chains: Policy Options to Build More Resilient Production Networks", Tackling the Coronavirus (COVID-19): Contributing to a Global Effort, 3 June. 